\title{
Uusioersily
}

\section{Biosurfactant/s from Lactobacilli species: Properties, challenges and potential biomedical applications}

Satpute, SK., Kulkarni, GR., Banpurkar, AG., Banat, I. M., Mone, NS., Patil, RH., \& Cameotra, SS. (2016).

Biosurfactant/s from Lactobacilli species: Properties, challenges and potential biomedical applications.

JOURNAL OF BASIC MICROBIOLOGY, 56, 1-19. https://doi.org/10.1002/jobm.201600143

Link to publication record in Ulster University Research Portal

Published in:

JOURNAL OF BASIC MICROBIOLOGY

Publication Status:

Published online: 20/07/2016

DOI:

10.1002/jobm.201600143

Document Version

Author Accepted version

\section{General rights}

Copyright for the publications made accessible via Ulster University's Research Portal is retained by the author(s) and / or other copyright owners and it is a condition of accessing these publications that users recognise and abide by the legal requirements associated with these rights.

\section{Take down policy}

The Research Portal is Ulster University's institutional repository that provides access to Ulster's research outputs. Every effort has been made to ensure that content in the Research Portal does not infringe any person's rights, or applicable UK laws. If you discover content in the Research Portal that you believe breaches copyright or violates any law, please contact pure-support@ulster.ac.uk. 


\title{
Review
}

\section{Biosurfactant/s from Lactobacilli species: Properties, challenges and potential biomedical applications}

\author{
Surekha K. Satpute ${ }^{1}$, Gauri R. Kulkarni ${ }^{1,2}$, Arun G. Banpurkar ${ }^{1}$, Ibrahim M. Banat ${ }^{3}$, \\ Nishigandha S. Mone ${ }^{1}$, Rajendra H. Patil ${ }^{4}$ and Swaranjit Singh Cameotra ${ }^{5}$ \\ ${ }^{1}$ Department of Physics, Centre for Advanced Studies in Materials Science and Condensed Matter Physics, \\ Savitribai Phule Pune University, Pune, Maharashtra, India \\ 2 Department of Physics, School of Basic Medical Sciences, Savitribai Phule Pune University, Pune, \\ Maharashtra, India \\ ${ }^{3}$ School of Biomedical Sciences, University of Ulster, Coleraine, N. Ireland, UK \\ ${ }^{4}$ Department of Biotechnology, Savitribai Phule Pune University, Pune, Maharashtra, India \\ ${ }^{5}$ Institute of Microbial Technology, Chandigarh, India
}

Lactic acid bacteria are generally believed to have positive roles in maintaining good health and immune system in humans. A number of Lactobacilli spp. are known to produce important metabolites, among which biosurfactants in particular have shown antimicrobial activity against several pathogens in the intestinal tract and female urogenital tract partly through interfering with biofilm formation and adhesion to the epithelial cells surfaces. Around 46 reports are documented on biosurfactant production from Lactobacillus spp. of which six can be broadly classified as cell free biosurfactant and 40 as cell associated biosurfactants and only approximately $50 \%$ of those have reported on the structural composition which, in order of occurrence were mainly proteinaceous, glycolipidic, glycoproteins, or glycolipopeptides in nature. Due to the proteinaceous nature, most biosurfactant produced by strains of Lactobacillus are generally believed to be surlactin type with high potential toward impeding pathogens adherence. Researchers have recently focused on the anti-adhesive and antibiofilm properties of Lactobacilli-derived biosurfactants. This review briefly discusses the significance of Lactobacilliderived biosurfactants and their potential applications in various fields. In addition, we highlight the exceptional prospects and challenges in fermentation economics of Lactobacillus spp.-derived biosurfactants' production processes.

Keywords: Biosurfactant / Biofilm / Biomedical / Lactobacilli / Surlactin

Received: March 8, 2016; accepted: June 6, 2016

DOI 10.1002/jobm.201600143

\section{Introduction}

Probiotic lactic acid bacteria have an important role in most dairy-based fermentation processes and Lactobacillus is one of its most important genera [1]. Lactobacillus spp. together with Streptococcus are often used in combination in many dairy products for their acid and flavor production capacity. It is important to note that both of this bacterial spp. are known to displace adhering uropathogenic bacteria such as

Correspondence: Surekha K. Satpute, Department of Physics, Centre for Advanced Studies in Materials Science and Condensed Matter Physics, Savitribai Phule Pune University, Pune 411007, Maharashtra, India

E-mail: drsurekhasatpute @gmail.com

Co-correspondence: Arun G. Banpurkar

E-mail: arunbanpurkar@gmail.com
Enterococcus faecalis from hydrophobic and hydrophilic substrata in a parallel-plate flow chamber which may be through biosurfactant/s production [2]. We are mostly concerned with the safe role of the genus Lactobacillus in relation to food and health issues. Among several metabolites, the food industries have extensively exploited the usage of lactic acid produced by Lactobacilli strains [3]. It is important, however, to emphasize that not all Lactobacilli strains are beneficial and harmless; some may be infective in patients suffering from human immunodeficiency virus [4].

Members of the Lactobacilli spp. have been long known as one of the potential biosurfactant producers although their biosurfactant products have not been completely characterized. A multi component mixture 


\section{Journal of Basic Microbiology}

with various proportions of protein and polysaccharidesbased biosurfactant with exceptional medical applications has been reported [2, 5-7]. In addition to biomedical application considerations, the biosurfactants have been utilized for biodegradation of polluting hydrocarbons. For example, Thavasi et al. [8] reported biosurfactant production by L. delbrueckii cultured on peanut oil cake up to $5.35 \mathrm{mg} \mathrm{ml}^{-1}$ where the biosurfactant product is used for bioremediation purposes and authors also reported enhanced emulsification with biodegradation potential of hydrocarbon pollutants. Even in the crude form of extracts, the lactic acid bacteria derived biosurfactants certainly find suitability for environmental applications.

Several review papers have discussed Lactobacilli spp. for their potential biomedical applications while few articles converse for lactic acid bacteria originated biosurfactants production with structural details. The work combining Lactobacilli producing biosurfactants with their biomedical potential has not been adequately reported in literature. However, this is the first review article discussing the complete chemical composition wise details on Lactobacillus-derived biosurfactants. In this review, we endeavor to highlight possible advantages and benefits of biosurfactant producing Lactobacilli strains in some products and technologies.

\section{Biosurfactant producing Lactobacilli spp.}

Lactobacilli are known to produce a variety of metabolic by-products in addition to biosurfactants, some of which have antimicrobial activity including lactic acid, hydrogen peroxide, bacteriocins, and bacteriocin-like substances (Fig. 1) which has imperative medical-related advantages [9]. Biosurfactants for example can play a crucial role in reducing the adherence capacity of several pathogens which is a necessary step for biofilm proliferation and formation [10]. Antimicrobial activities and ability to interfere with pathogens adhesion to the urogenital and intestinal tracts epithelial cells leads to an ability to act as antibiofilm agent. Such biofilms are quite common on surgical wounds, silicone-based devices [11], catheters, intravenous catheters, and cardiac devices and other prostheses [12, 13]. Studies carried out by Gan et al. [14] highlighted the utility of Lactobacilli and its biosurfactant in the prevention of surgical implant infection in vivo.

Detailed studies on several mechanisms of interference of pathogen adherence and biosurfactant have been previously reported by several researchers [15-18]. The mechanism of competitive exclusion has been demonstrated by quite a lot of Lactobacilli spp. where their surface protein namely the co-aggregation-promoting factor (Cpf) mediates co-aggregation with the human pathogenic microorganisms. This co-aggregation mechanism inhibits the adherence of pathogens to the epithelial cells of the host tissue effectively creating a barrier that prevents colonization by pathogens [19]. Autoaggregation of probiotic strains is obligatory for adherence to epithelial cells and surfaces of mucus, which consequently supports their accumulation and growth in those environments. This phenomenon has been well documented by studies mostly carried out in oral cavity and the urogenital tract [20].

"Biosurfactants" are products known to reduce surface tension and interfacial tension and to have activity at interfaces. Numerous classes of biosurfactants have so far been described according to their chemical structure, producing strain and mode of action [21]. At present, we are aware of several potential

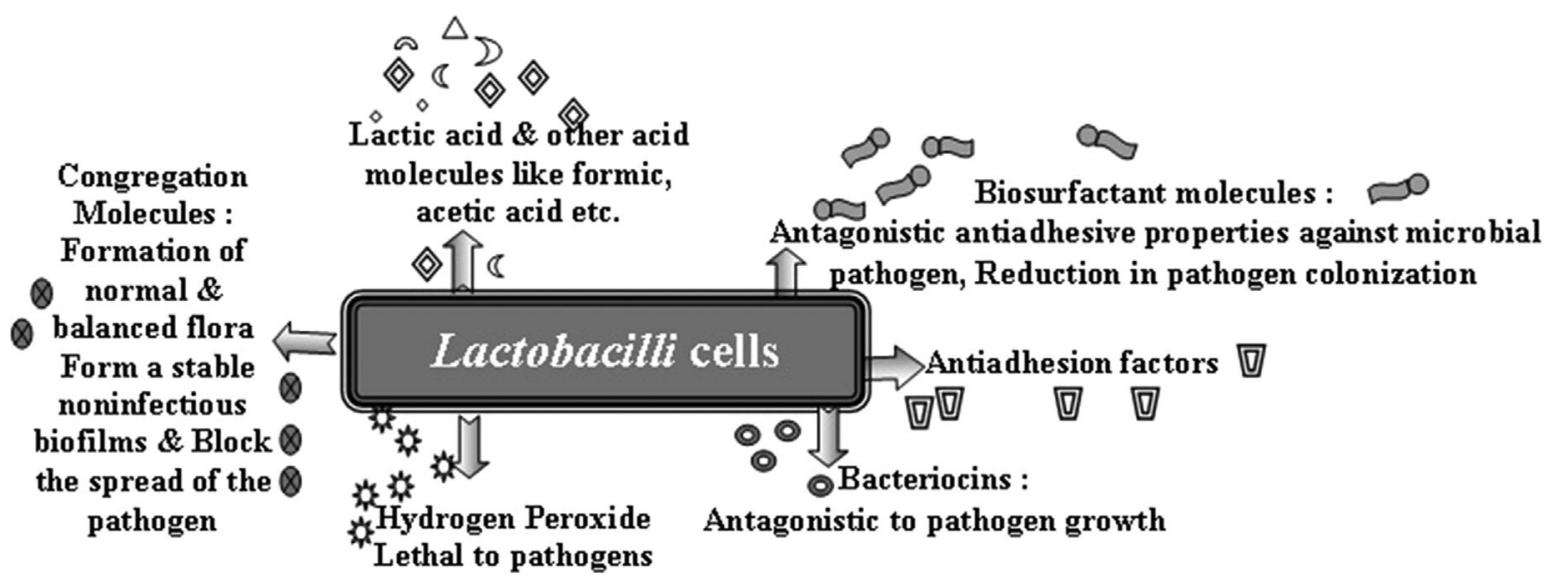

Figure 1. Secretion of various antimicrobial compounds by Lactobacilli cells. 


\section{Journal of Basic Microbiology}

Biosurfactant/s from Lactobacilli species

applications of biosurfactants in the surfactant industry [22]. Glycolipids, lipopeptides, protein-like substances, phospholipids, fatty acids, and lipopolysaccharide produced by Lactobacilli spp. have been characterized by several researchers [23-25]. About 46 research outputs reported Lactobacilli spp. biosurfactant production, 6 of which are cell free biosurfactant and 40 cell associated biosurfactant. Based on the preliminary studies, two reports including Ceresa et al. [11] and Fracchia et al. [26] have proposed the presence of cell free biosurfactant as multi-component complex that can show presence of sugar moieties while single report by Thavasi et al. [8] describes a glycolipid-type cell free biosurfactant. The other three research articles available on cell free biosurfactant without revealing much specification on chemical characterization [27-29].

In comparison, among the 40 cell associated biosurfactant reports, about half (50\%) do not disclose any structural details most likely due to the complex structures that are difficult to elucidate. It is important to highlight that surlactin/and or proteinaceous cell associated biosurfactant (32.5\%) appears to be most frequently produced by Lactobacilli spp. Glycolipid (5\%) type of biosurfactants are also produced from probiotic bacterial cultures $[24,30]$. Few reports mentioned glycoproteins $(7.5 \%)[23,31,32]$ and glycolipopeptide (5\%) production $[25,33]$.

Most of the focus for cell associated biosurfactant usage appears toward their anti-adhesive and antibiofilm activities [12, 34]. Few reports do mention their antimicrobial activity of cell associated biosurfactant $[15,16,35]$. Recently, we have discussed the general role of several biosurfactants molecules in biofilms formation and inhibition $[10,36]$. Biosurfactants molecules offer many advantages over synthetic surfactants including biodegradability and lower toxicity which makes them supreme candidates for various biomedical applications [21, 37-40]. Their great diversity offers varying properties leading to a number of different applications in various fields $[39,41-46]$. Biosurfactant support the microbial entities to grow on hydrophobic or water-immiscible substrates through various mechanisms like lowering the surface tension and interfacial at the phase boundary [43]. Other properties such as wetting, foaming, emulsification affects the adhesion of microbial cells to the organic substrates. A wide variety of Lactobacilli spp. produces varied types of biosurfactants substances as presented in Table 1.

To date a large number of researchers have investigated biosurfactant producing Lactobacilli spp. including L. casei sub spp. rhamnosus 36 and ATCC 7469,
L. fermentum B54 and L. acidophilus RC14. These strains produce biosurfactants during their mid-exponential $(4-5 \mathrm{~h})$ and stationary growth phases $(18 \mathrm{~h})$ lowering surface tension [5]. The role of such biosurfactants by Lactobacilli in their natural environment appears to be mainly related to the reduction of adhesion of numerous uropathogens to epithelial cells [9]. Biosurfactants have also been used frequently against microbes and infections in the urinary, vaginal, gastrointestinal tracts, and skin [15]. Often the activity of biosurfactant is mostly related to an inhibition of pathogen adhesion rather than a direct antimicrobial activity or inhibition of the cell growth [48]. Anti-adhesive properties of biosurfactants have a significant role in preventing the adhesion of pathogenic bacteria [34] in addition to the rate of bacterial deposition as well as biofilm development [32, 54]. Biosurfactants also have a great potential in preventing microbial colonization on food contact surfaces $[24,55,56]$ and also used in the formulations from food-based industry to reduce pathogens adhesion to human epithelial cell receptors [49].

It should be noted that the composition of protein and polysaccharide fractions of glycoproteins biosurfactant from Lactobacilli are affected by the composition of the medium, time, $\mathrm{pH}$, temperature of incubation, inoculums volume, and the growth phase of bacteria [47]. Yeast extract is essential for bacterial growth, while peptone is crucial for biosurfactant synthesis. Gudiña et al. [17] stated that the use of peptone and meat extract yields a higher production as compared to the standard medium like de Man, Rogosa, and Sharpe medium [57]. The presence of magnesium and manganese were also reported to be essential for bacterial growth and surlactin (protein rich biosurfactant produced by Lactobacilli spp.) production [26]. Other environmental parameters like $\mathrm{pH}$, temperature also determines the activity of biosurfactant [16]. The de Man, Rogosa, and Sharpe medium has been usually used for growth and production of various types of biosurfactants from Lactobacilli spp.

Proteinaceous biosurfactants have high binding affinities to the various materials such as catheters, medical devices $[5,6]$. It is also important to note that factors other than biosurfactant do interfere with uropathogenic biofilm formation [44]. Lactobacillus spp.-derived biosurfactant can also inhibit biofilm formed by Candida albicans $[11,26]$. Recent report on the biosurfactant derived from L. brevis isolate (CV8LAC) has proved its effectiveness as an anti-adhesive product for several medical devices such as catheters, stents, and prosthesis leading to the reduced colonization and prevention of C. albicans infections [11]. 


\section{Journal of Basic Microbiology}

Surekha K. Satpute et al.

Table 1. Brief description on types, production, and characterization of Lactobacilli-derived biosurfactants along with their potential applications.

\begin{tabular}{|c|c|c|c|c|}
\hline Lactobacilli spp. & Type of biosurfactant (BS) & $\begin{array}{l}\text { Production and } \\
\text { characterization }\end{array}$ & Potential application & Ref. \\
\hline $\begin{array}{l}\text { - L. acidophilus RC14 } \\
\text { - } \text { L. casei } 70 \\
\text { - } \text { L. casei subsp, rhamnosus GR-1 }\end{array}$ & $\begin{array}{l}\text { RC14 and B54 produce BS rich } \\
\text { in protein and less content of } \\
\text { polysaccharide, phosphate }\end{array}$ & $\begin{array}{ll}\text { - } & \text { Freeze-drying } \\
\text { - } & \text { FTIR } \\
\text { - X-ray PS }\end{array}$ & $\begin{array}{l}\text { Protein like BS from } \\
\text { B54 and RC14 } \\
\text { effectively inhibit the } \\
\text { adhesion of E. faecalis } \\
\text { to glass surface }\end{array}$ & {$[5]$} \\
\hline
\end{tabular}

- L. plantarum RC6 \& RC20 36 and B54 produce BS rich in (isolated from urogenital protein with phosphate, tract of healthy woman)

- L. casei subsp. rhamnosus 36 polysaccharide, presence of ester carbonyl group (isolated from a woman with a history of urogenital infections)

- L. acidophilus T13, L. fermentum B54 (poultry isolate)

- L. casei subsp, rhamnosus 81 (dairy isolate)

All 15 Lactobacillus isolates produce protein like BS in mid-exponential and

stationary growth phase

- L. casei subsp., rhamnosus 36 (isolated from a woman with a history of urogenital infections)

Surlactin: the protein rich BS, shows the presence of lipoteichoic acid with molecular weight from 14.4 to $>94 \mathrm{kDa}$

Surlactin: the protein rich BS

- Centrifugation

- Filtration

- Dialysis

ATCC 7469 (American Type Culture Collection)

- L. fermentum B54 (poultry isolate)

- L. acidophilus RC14 (isolated from urogenital tract of healthy woman)

- L. acidophilus RC14

- L. acidophilus R14

- L. fermentum RC-14

- L. fermentum B54

- L. rhamnosus 36
- FTIR

- X-ray PS

- AAA

- SDS-PAGE
Surlactin: protein, polysaccharides possibly bound to phosphate groups

Composition not stated

Produce anti-adhesive, proteinaceous BS

Do not release anti-adhesive Not stated
Protein rich BS that may interfere with uropathogen adhesion
[6]

Inhibit initial

[2] adhesion of uropathogenic $E$. faecalis. Important for development of antiadhesive biological coatings for catheter

Inhibit initial adhesion of few
- Centrifugation

- Filtration

- Dialysis

- Centrifugation

- Filtration

- Dialysis

Not stated uropathogens

Inhibit adhesion of E. faecalis and other urophathogens

Inhibit initial adhesion of E. faecalis 


\section{Journal of Basic Microbiology}

Biosurfactant/s from Lactobacilli species

Table 1. (Continued)

\begin{tabular}{|c|c|c|c|}
\hline Lactobacilli spp. & Type of biosurfactant (BS) & $\begin{array}{l}\text { Production and } \\
\text { characterization }\end{array}$ & Potential application Ref. \\
\hline $\begin{array}{l}\text { - L. rhamnosus ATCC } 7469^{\mathrm{T}} \\
\text { (American Type Culture } \\
\text { Collection) }\end{array}$ & $\begin{array}{l}\text { Do not release anti-adhesive } \\
\text { BS }\end{array}$ & Not stated & \\
\hline
\end{tabular}

- L. fermentum RC-14

- L. casei Shirota

- L. rhamnosus GR-1

- L. rhamnosus GR-36

- L. fermentum RC-14

- L. rhamnosus GR 1

- L. casei CECT-5275

- L. rhamnosus CECT-288

- L. pentosus CECT-4023

- L. coryniformis subsp. Torquens CECT-25600 (Obtained from the Spanish Collection of Type Cultures, Valencia, Spain)

- L. fermenti 126

- L. acidophilus PG 8/4

- L. rhamnosus CCM 1825

- L. acidophilus $\mathrm{H}-1$

- L. acidophilus 336

- L. acidophilus Ch-2 Rhodia Food (Biolacta Company, Olsztyn, Poland)

- L. casei 8/4 (A culture collection of the Department of Industrial and Food Microbiology, University of Warmia and Mazury in Olsztyn, Poland)

- L. paracasei ssp. paracasei A20 (Portuguese dairy plant, Composition not stated Portugal)
Number of collagen-binding proteins in the crude BS

\section{Composition not stated}

Crude BS

Composition not stated

-Centrifugation

-Extraction
- Filtration

- Centrifugation

- Filtration

- Dialysis

- Lyophilization

- SELDI WCX-1 Protein Chip technology

- Collagen cross-linked PS-1 Protein Chip arrays

- AAA
Surface-enhanced laser desorption/ ionization (SELDI) Protein - Rapid characterization of proteins and proteinprotein interactions infections caused by S. aureus

L. pentosus CECT-4023, [13] strong BS producer, Cheese whey alternative medium for BS production

Glycoprotein type: the protein - Dialysis content $8.7 \mathrm{mg}$ (LAA H-1), $4.5 \mathrm{mg}$ (LAA 336), $9.1 \mathrm{mg}$ (LAA

- Freeze-drying

Ch-2), per $g$ of dry mass
- Centrifugation

Anti-adhesive property

Inhibitors of S. aureus, S. epidermidis adhesion and biofilm development

\author{
phosphoric groups
}

Glycoproteins with additional

- Centrifugation

- Filtration

- Dialysis

- FTIR

- NuPAGE electrophoresis

- Membrane

- Filtration

- Freeze-drying
Exhibit antimicrobial properties may be applied in food stuffs, which is likely to result in a reduction of pathogenic microflora count

Antimicrobial and anti-adhesive 


\section{Journal of Basic Microbiology}

Surekha K. Satpute et al.

Table 1. (Continued)

\begin{tabular}{llll}
\hline Lactobacilli spp. & Type of biosurfactant (BS) & $\begin{array}{l}\text { Production and } \\
\text { characterization }\end{array}$ & Potential application Ref. \\
\hline
\end{tabular}

- L. paracasei ssp. paracasei A20 (Portuguese dairy plant, Portugal)

- L. acidophilus (Vaginal swabs of healthy women, Kamal Al-Samaraei and Al-Alweia) (Maternity Hospitals in Baghdad)

- Lactobacillus spp. CV8LAC (Fresh fruits and vegetables Italy)

- L. paracasei ssp. paracasei A20

- L. plantarum A14 (Portuguese dairy plant)

- L. fermenti 126

- L. rhamnosus CCM 1825 (Culture Collection of the Chair of Industrial and Food Microbiology (CCCIFM)), (University of Warmia and Mazury (UWM)) in Olsztyn, Poland

- L. delbrueckii (Marine waters, Tuticorin Port, Tamil Nadu, India)

- L. acidophilus Leibniz Institute DSMZ-(German Collection of Microorganisms and Cell Cultures)

10 Lactobacilli species (traditional Egyptian dairy products collected from the CairoMarkets, Egypt)

- L. pentosus
Crude BS

Composition not stated

Surlactin: glycoprotein Molecular weight $60-80 \mathrm{kDa}$

Mixture of various components including presence of sugar

Composition not stated

Protein, polysaccharide and phosphate in different ratio
- Centrifugation

- Membrane filtration

- Dialysis

- Freeze-drying

- Centrifugation

- Membrane filtration

- Gel filtration

- Dialysis

- Freeze-drying

- Filtration

- Ultrafiltration

- TLC

- Centrifugation

- Supernatant

- Extraction

- FTIR

- Capillary gel electrophoresis
Antimicrobial, anti-

[16] dhesive activities against several pathogens

Crude surlactin in stationary phase of growth. Highly stable at $\mathrm{pH} 6$ and high temperature conditions

The anti-adhesive properties against $C$. albicans biofilm

L. paracasei ssp. paracasei A20 as a promising BSproducer

Good anti-adhesive properties against Enterobacteriaceae
Glycolipid with carbohydrate and lipid combination of 30\%:70\% (w/w)

- FTIR

- MS

Protein-like component with presence of polysacchardies and phosphate fractions

Crude BS: composition not stated

- Centrifugation

- Filtration

- Dialysis

- FTIR

- Centrifugation

- Acidification

- Extraction

- Evaporation

Mostly protein rich fraction
- Not stated
BS alone can promote [8] biodegradation to a large extent without adding fertilizers

Interfere in the adhesion, biofilm formation of the S. mutans to glass

Distinct antimicrobial, antiadhesive activities against pathogens

The adsorption properties of BS onto sediments present it as a potential foaming agent in froth flotation 


\section{Journal of Basic Microbiology}

Biosurfactant/s from Lactobacilli species

Table 1. (Continued)

\begin{tabular}{|c|c|c|c|c|}
\hline Lactobacilli spp. & Type of biosurfactant (BS) & $\begin{array}{l}\text { Production and } \\
\text { characterization }\end{array}$ & Potential application & Ref. \\
\hline $\begin{array}{l}\text { - L. pentosus CECT-4023 T } \\
\text { (ATCC-8041) (Spanish Collec- } \\
\text { tion of Type Cultures } \\
\text { Valencia, Spain) }\end{array}$ & $\begin{array}{l}\text { Glycoproteins, or } \\
\text { glycolipopeptide }\end{array}$ & $\begin{array}{l}\text { - Centrifugation } \\
\text { - Filtration }\end{array}$ & $\begin{array}{l}\text { Bioremediation of } \\
\text { hydrocarbon- } \\
\text { contaminated soil }\end{array}$ & {$[25]$} \\
\hline $\begin{array}{l}\text { - L. plantarum CFR } 2194 \text { (Iso- } \\
\text { lated from kanjika, rice- } \\
\text { based ayurvedic fermented } \\
\text { product) }\end{array}$ & $\begin{array}{l}\text { Glycoprotein - protein, } \\
\text { polysaccharide fractions }\end{array}$ & $\begin{array}{l}\text { - Centrifugation } \\
\text { - Filtration } \\
\text { - Dialysis } \\
\text { - Freeze-drying }\end{array}$ & $\begin{array}{l}\text { Anti-adhesive } \\
\text { property against food- } \\
\text { borne pathogens }\end{array}$ & {$[23]$} \\
\hline - Lactobacilli strain & $\begin{array}{l}\text { Glycolipid (lipid and sugar } \\
\text { fractions) closely similar to } \\
\text { xylolipids }\end{array}$ & $\begin{array}{l}\text { - Centrifugation } \\
\text { - Filtration } \\
\text { - Gel filtration } \\
\text { - Dialysis } \\
\text { - Freeze-drying } \\
\text { - FTIR, NMR } \\
\text { - TGA }\end{array}$ & $\begin{array}{l}\text { Proposed application } \\
\text { of BS for oral } \\
\text { consumption and } \\
\text { biomedical } \\
\text { applications }\end{array}$ & {$[24]$} \\
\hline
\end{tabular}

- L. casei MRTL3 (raw milk)

- L .jensenii

- L. rhamnosus

- L. rhamnosus (isolated from Crude biosurfactant vagina of Iraqi healthy women was studied)

- L. reuteri DSM20016 (Probi- Cell associated BS otic source)

- L. pentosus

- L. brevis CV8LAC (fresh cabbage obtained from a producer of biological fruit, vegetables in a rural area of Piedmont, Italy)
Glycolipids - mixture of lipid • Centrifugation and sugar

Composition not stated

- TLC, FTIR

- NMR

- TEM
- Centrifugation

- Acidification

- Extraction

- Evaporation

- Centrifugation

- Cell collection

- Resuspension

- Supernatant

- Filtration

- Dialysis

- Freeze-drying

- Centrifugation

- Extraction glycolipopeptide type composed of C:18 and C:16 fatty acids

BS with mixture of components including sugar as one of the fractions
- Centrifugation

- Acidification

- Extraction

- Evaporation
Antibacterial against 8 cultures

[30]

Antimicrobial, antiadhesive, anti-biofilm activities against

A. baumannii, E. coli, S. aureus

Inhibitory effect on adherence and biofilm formation of E. coli, S. aureus, K. pneumoniae, B. cepacia

Inhibitor of the glucosyltransferases and fructosyltransferase strain of S. mutans (ATCC35668) affect initial adhesion to the tooth surface

Higher emulsion volumes and stable emulsions than polysorbate 20

Inhibition of adhesion, [11] biofilm formation of $C$. albicans on medicalgrade silicone elastomeric disk(SEDs) 


\section{Journal of Basic Microbiology}

Table 1. (Continued)

\begin{tabular}{|c|c|c|c|c|}
\hline Lactobacilli spp. & Type of biosurfactant (BS) & $\begin{array}{l}\text { Production and } \\
\text { characterization }\end{array}$ & Potential application & Ref. \\
\hline - L. agilis CCUG31450 & Glycoprotein & $\begin{array}{l}\text { - Centrifugation } \\
\text { - Filtration } \\
\text { - Gel filtration } \\
\text { - Dialysis } \\
\text { - Freeze-drying } \\
\text { - FTIR }\end{array}$ & $\begin{array}{l}\text { Anti-adhesive activity } \\
\text { against } \\
S \text {. aureus, and } \\
\text { antimicrobial activity } \\
\text { against } S \text {. aureus, } \\
\text { S. agalactiae, } P \text {. } \\
\text { aeruginosa }\end{array}$ & {$[31]$} \\
\hline - L. acidophilus ATCC 4356 & $\begin{array}{l}\text { Proteinaceous BS with } \\
\text { presence of polysaccharides } \\
\text { and phosphate fractions }\end{array}$ & $\begin{array}{l}\text { - Centrifugation } \\
\text { - Filtration } \\
\text { - Gel filtration } \\
\text { - Dialysis } \\
\text { - Freeze-drying } \\
\text { - FTIR }\end{array}$ & $\begin{array}{l}\text { The inhibitory effect } \\
\text { on biofilm forming } S \text {. } \\
\text { marcescens }\end{array}$ & {$[46]$} \\
\hline
\end{tabular}

BS, biosurfactant; FTIR, Fourier transform infrared spectroscopy; HPLC, high performance liquid chromatography; AAA, amino acid analysis; MS, mass spectroscopy; NMR, nuclear magnetic resonance; TGA, thermal gravimetric analysis; TLC, thin layer chromatography; ASP, ammonium sulphate precipitation; X-ray PS, X-ray photoelectron spectroscopy; TEM, transmission electron microscopy.

Note: Information available on the chemical structure of biosurfactants produced by genus Lactobacilli is not adequate. Researchers, namely, Velraeds et al. [2, 5-7, 43], Howard et al. [44] demonstrated biosurfactant production from Lactobacillus strains which were isolated previously by Reid et al. [53].

\section{Lactobacilli lipopeptides - composition, chemical structures, and mechanisms of action}

It is well known that biosurfactant molecules can be quite complex and often composed of carbohydrates, proteins, and lipids mixtures. To date, glycolipids, glycolipopeptide, glycoprotein with or without additional phosphoric groups have been reported to be produced by Lactobacilli's thorough utilizing the several analytical techniques such as Fourier transform infrared spectroscopy, nuclear magnetic resonance $\left({ }^{1} \mathrm{H}\right.$ and $\left.{ }^{13} \mathrm{C}\right)$, gas chromatography mass spectrometry (GC-MS), liquid chromatography-mass spectrometry (LC-MS), high performance liquid chromatography (HPLC) among others. From the literature survey, it appears that protein-based biosurfactants has been reported very frequently from Lactobacilli spp. in comparison with glycolipopeptide/ glycolipoprotein. Often the hydrophobic chain of biosurfactant is composed of lipids, whereas the hydrophilic chain is mostly composed of proteins or sugar moieties conferring unique properties. Sometimes the biosurfactant molecules are complex and difficult to determine, see Table 1 for common biosurfactants produced by Lactobacilli strains. Many such complex structures have been reported for either anti-adhesive, antibiofilm, or as antimicrobial agents against several pathogenic strains. Currently, cell free biosurfactant (only $13 \%$ reports available) and cell associated biosurfactant $(\sim 87 \%$ reports) have been obtained from Lactobacilli spp.

\section{The success story of surlactin}

Researchers have classified biosurfactants broadly as low molecular weight (glycolipids, short chain containing lipopetides) and high molecular weight (bioemulsifierbased polymeric and lipopeptides). Among which rhamnolipids and surfactin represents the most extensively characterized low molecular weight biosurfactants. Production of rhamnolipid (due to the presence of rhamnose moiety) from Pseudomonas pyocyanea (currently known as P. aeruginosa) was documented by Bergström et al. [58]. Since 1968 surfactin (term coined due to strong surfactant activity greater than synthetic surfactant namely sodium lauryl sulphate), a crystalline lipopeptide-type biosurfactant which is routinely isolated from cell free supernatant produced by Bacillus subtilis [59]. Today, rhamnolipid and surfactin have been widely exploited for various industrial purposes. Initially, all surfactin compounds were considered as antimicrobial agents which later on subsequent studies proved them as surface active agents. Similarly, about in mid-1990s 


\section{Journal of Basic Microbiology}

Biosurfactant/s from Lactobacilli species

researchers started hunting for health associated benefits of lactic acid bacteria, probiotics and their metabolites. The biosurfactants produced by Lactobacilli spp. are believed to interfere the pathogenicity confer by microbes through different mechanisms, where it is believed that biosurfactant plays a critical role [12]. The equation like rhamnolipid only from Pseudomonas spp., surfactin type only from Bacillus spp., and surlactin type only from Lactobacillus spp. can be considered authentically.

Velraeds et al. [5] started talking about biosurfactant from various Lactobacilli strains where L. acidophilus exhibited production of protein rich cell associated biosurfactant with presence of small fractions of polysaccharides and phosphates. Parallel studies reported by same researchers [6] coined the terminology namely "Surlactin" for the first time. They described the surlactin as a protein rich cell associated biosurfactant, released by specific strains of Lactobacillus spp. during stationary phases and enough competent to interfere the adhesion of uropathogens. Further contribution in the subsequent year by same researchers [2] could demonstrate the inhibitory effect of $L$. acidophilus-derived surlactin-type biosurfactant against uropathogenic E. faecalis on silicone-based surface rather than glass surface. Subsequently, fourth report appeared from research group of Velraeds et al. [7] confirmed the role of "surlactin" obtained from L. acidophilus RC14 for inhibition of initial adhesion of uropathogens in addition to two yeast strains on silicone rubber. Surlactin again proved to have a marked inhibitory effect against tested pathogens including both strains of Candida. From the overview of literature, it is imperative to emphasize that greatest contribution about surlactin is put forward by the authors from Velraeds research group.

In the year 2010, Fouad and coworkers [47] described the surlactin as a glycolipoprotein complex produced using L. acidophilus. Authors characterized glycolipoprotein with a molecular weight of $60-80 \mathrm{kDa}$ through gel filtration studies and also highlighted that presence of magnesium $(0.04 \%)$ and manganese sulfate $(0.01 \%)$ are essential for the growth of the strain as well as for the production of surlactin.

An interesting piece of work is contributed by Munira and coworkers [60] on surlactin derived from L. acidophilus using different strains. Authors have commented that different strains of Lactobacilli produce varied type of surlactin and therefore, it is obvious to behave differently to display the mechanism of action. Their efforts were toward investigating the biological applications of surlactin to inhibit the adhesion of biofilm forming pathogenic strain like P. aeruginosa on contact lenses. Their results demonstrated the capability of surlactin to inhibit the adhesion of pathogens up to $60 \%$ without any antibacterial activity. The surlactin proved to be effective for treating the infection in rabbits' eyes with $P$. aeruginosa. Furthermore, their studies also proved that infection with $P$. aeruginosa (administrated to rabbits' eyes) can be prevented by using surlactin. However, no satisfactory results were found against Staphylococcus aureus culture. Recent studies appeared from Vecino et al. [50] proved the chemical composition of surlactin through using analytical techniques like Fourier transform infrared spectroscopy, to indicate presence of protein rich fractions.

Overall cell associated biosurfactant produced by certain Lactobacilli strains having high proteinaceous (could be a complex of glycoprotein or glycolipoprotein) can be claimed as surlactin-type biosurfactant. Based on Velraeds et al. [2] terms and observation, a definition for surlactin is advised by Fouad et al. [47] claiming that surface active agents produced by Lactobacillus strains or surface lactin. The fact that the term surlactin is appeared due to the complexity in chemical structure which can be compared with mucoproteins which has abilities to adhere to the surfaces. Few researchers have reported cell associated biosurfactant as a combination of proteins with the presence of sugar or lipid moieties. However, we shed a light suggesting that there are researchers who have not used the terminology "surlactin" for biosurfactant isolated by them instead they described only as proteinaceous-type biosurfac$\operatorname{tant}[46,48,49]$.

\section{Biosurfactant obtained from cell free supernatant}

Most of the low molecular weight biosurfactants of microbial origin (rhamnolipid, surfactin, cyclic lipopeptides, iturins, fengycins) have been reported to be released extracellularly, and have occupied global market including, transplantation, devices manufacturing units. Handling of these compounds for commercial purposes seems to be uncomplicated where many coating formulations have been designed to protect implant materials. Closer observation on available literature about genus Lactobacillus put forward that secretion of cell free biosurfactant is not reported much frequently. Chemical composition wise, generally cell free biosurfactant from a small number of Lactobacillus spp. are produced as mixture of various compounds, however, distinct work contributed by Thavasi et al. [8] suggests that cell free biosurfactant can be of glycolipid type. They reported production of cell free biosurfactant L. delbrueckii of having a combination of carbohydrate 


\section{Journal of Basic Microbiology}

(30\%) and lipid (70\%) evident through Fourier transform infrared spectroscopy analysis suggesting the presence of significant bands at 2962, 2924, and $2854 \mathrm{~cm}^{-1}$ (for the $\mathrm{CH}$ aliphatic stretching), $1061 \mathrm{~cm}^{-1}$ (PII band: polysaccharides), $1793 \mathrm{~cm}^{-1}$ (for the $\mathrm{C}=\mathrm{O}$ ester bond), 3388 and $3696 \mathrm{~cm}^{-1}$ (for OAH bonds), and 766, $700 \mathrm{~cm}^{-1}$ (for the $\mathrm{CH}_{2}$ group). The overall analytical observations illustrated the presence of different fractions in biosurfactant which can be claimed as glycolipid type. Mass spectroscopic analysis $(\mathrm{m} / \mathrm{z}=326.5$ and at 663.4 for lipid and glycolipid moieties) also confirm the data obtained by Fourier transform infrared spectroscopy.

Even though, cell free biosurfactant possessing the mixture of various components (including sugars) do have a noteworthy key role in biomedical applications. Studies by Ceresa et al. [11] demonstrated the production of cell free biosurfactant (structure not determined) from L. brevis (CV8LAC) which prevents the adhesion of C. albicans on medical-grade silicone elastomeric disks. Thus authors have proved cell free biosurfactant as hopeful aspirant for biomedical approaches. At a concentration of $2000 \mu \mathrm{g} \mathrm{ml}^{-1}$, cell free biosurfactant also reduced biofilm formation by C. albicans by 89 and $90 \%$ after 24 and $72 \mathrm{~h}$ of incubation. Similarly, Fracchia et al. [26] reported on the antibiofilm activity of CV8LAC cell free biosurfactant against Candida cultures which has many appealing applications.

Augustin and Hippolyte [27] characterized cell free biosurfactant (without any structure details) from Lactobacillus spp. which was isolated from pendidam, a fermented milk product (local brand, Ngaoundere, Cameroon). The strain TM1 showed biosurfactant production potential in drop collapse $(7.30 \mathrm{~mm}$ of diameter), best emulsification ability $(56.80 \%)$, and also good reduction in interfacial tension values $(45.09 \mathrm{mN} /$ $\mathrm{m})$. The cell free biosurfactant obtained also has broad spectrum of antimicrobial activity against bacterial strains like Escherichia coli, B. cereus, Salmonella spp., and E. faecalis. Augustin and Hippolyte [27] proposed that antimicrobial activity of cell free biosurfactant represents as excreted factors and not as cell associated or cell surface components. No loss in the activity of cell free biosurfactant even after treatment at different conditions and therefore such surface active substances can be utilized in food preservation procedures to prevent their spoilage. On similar background, in the succeeding year, Augustin et al. [28] again reported cell free biosurfactant (no composition revealed) production from three strains of Lactobacillus spp. and showed good stability over a wide range of $\mathrm{pH}(6.0-12.0)$ and salinity $(5.0-15.0 \%)$. The cell free biosurfactant have huge potential for their antibacterial activities. Salman and Alimer [29] conducted experimental work to compare the cell free biosurfactant in crude and partially purified cell free biosurfactant to check the inhibitory effect against urinary tract infection causing bacteria like K. pneumonia, S. aureus, and B. cepacia. The researchers suggested that surface activity of cell free biosurfactant is good when it is in the crude form to impede the adherence as well as biofilm formed by those pathogenic bacteria.

\section{Cell bound or associated biosurfactant}

Proteinaceous composition. Many antibiotics, antimicrobial agents do possess protein as one of the major functioning fractions of the entire molecule. The proteinaceous nature or peptides do contribute toward antimicrobial activity and have tremendous potential for treating and/or preventing the infectious diseases. Risk of microbial resistance can be reduced certainly with the help of such proteinaceous molecules. Protein rich with and without polysaccharide, phosphate fractions in cell bound or cell associated biosurfactant originated from Lactobacillus spp. have undoubtedly fulfilled this expectations proving to combat pathogens. Several researchers could successfully document the potentiality of cell associated biosurfactant as antimicrobial, antibiofilm, and anti-adhesive agents.

Velraeds et al. [5, 6] reported on L. acidophilus RC14 and L. fermentum B54 strains producing proteinaceous rich biosurfactant where smaller fractions of polysaccharide and phosphate were also detected using Fourier transform infrared spectroscopy. Further their work on other strains namely L. Casei sub spp. Rhamnosus 36 and L. rhamnosus ATCC7469 showed production of protein, polysaccharide, and phosphate containing biosurfactant along with additional ester carbonyl group. The bands detected were at $2932 \mathrm{~cm}^{-1}(\mathrm{CH}$ band:CH2-CH3), $1652 \mathrm{~cm}^{-1}$ (AmI band:CAO stretching in proteins), $1537 \mathrm{~cm}^{-1}$ (AmII band: $\mathrm{NOH}$ bending in proteins). In addition bands at $1234 \mathrm{~cm}^{-1}$ (PI band: phosphates) and at $1066 \mathrm{~cm}^{-1}$ (PII band: polysaccharides) were also detected. Velraeds et al. [2] also reported surlactin-type protein rich biosurfactant from L. acidophilus RC14 which is a proficient ideal candidate for developing anti-adhesive biological coatings for catheterlike medical devices. The same group also reported protein and polysaccharides bound with phosphate fraction biosurfactant from L. acidophilus R14 [7].

Recent work by Shokouhfard et al. [46] reports protein rich containing polysaccharide-type biosurfactant from L. acidophilus ATCC 4356 which was detected by Fourier transform infrared spectroscopy analysis. They detected $2929 \mathrm{~cm}^{-1}$ (CH band: $\mathrm{CH} 2-\mathrm{CH} 3$ stretching), $1655 \mathrm{~cm}^{-1}$ (AmI band: CAO stretching) bands which indicates the 


\section{Journal of Basic Microbiology}

presence of proteins fractions. Polysaccharides with phosphate fractions were also confirmed with bands at $1402 \mathrm{~cm}^{-1}$ (AmII band: NOH), $1260 \mathrm{~cm}^{-1}$ (PI band: phosphates) and $1056 \mathrm{~cm}^{-1}$ (PII band: polysaccharides). The authors proposed the predominance of protein in glycopeptides biosurfactant having anti-adhesive against biofilms developed by $S$. marcescens strains.

Brzozowski et al. [48] also reported biosurfactant production by L. fermenti 126 and L. rhamnosus CCM 1825 having proteinaceous biosurfactant with an existence of polysaccharide and phosphates biosurfactant obtained L. rhamnosus CCM 1825 possessed more proteins and phosphates as compared with $L$. fermenti 126. The L. fermenti 126 produced biosurfactant had an excitations at the wavelengths of 3285,1653 , and $1549 \mathrm{~cm}^{-1}$, with a typical of stretching bonds $>\mathrm{N}-\mathrm{H}$, $\mathrm{CO}-\mathrm{N}$ (AmI protein band) and $\mathrm{N}-\mathrm{H}$ (AmII protein band) supporting the occurrence of proteinaceous components. L. rhamnosus CCM 1825-derived biosurfactant also shows excitation at similar wavelengths, i.e., 3287 , 1656 , and $1547 \mathrm{~cm}^{-1}$. The signal received for biosurfactants from L. fermenti 126 and L. rhamnosus CCM 1825 at the band of 2964, 2929, and $1458 \mathrm{~cm}^{-1}$, and 2961, 2936, and $1453 \mathrm{~cm}^{-1}$, respectively, corresponding to $\mathrm{C}-\mathrm{H}$ bonds of $-\mathrm{CH} 3,-\mathrm{CH} 2-$, and $>\mathrm{CH} 2$ groups of aliphatic chains. Brzozowski et al. [48] commented that the occurrence of a polysaccharide fraction in both biosurfactants is evident in the wavelength range from 1200 to $1000 \mathrm{~cm}^{-1}$. While the excitation spectrum at 1078 and $1083 \mathrm{~cm}^{-1}$ (PII polysaccharide band) is representative of bond vibrations in the $\mathrm{C}-\mathrm{O}-\mathrm{C}$ group. The absorbance at 1237 and $1240 \mathrm{~cm}^{-1}$ (PI phosphate bond) and 935 and $932 \mathrm{~cm}^{-1}$ were equivalent to the stretching bonds formed by phosphorus and oxygen atoms $(\mathrm{P}-\mathrm{O}-\mathrm{C})$ in aromatic and aliphatic molecules. The absorbance coefficients detected for AmI, AmII, PI, and PII bands, counted as the ratio to the $\mathrm{C}-\mathrm{H}$ band for the biosurfactant resulted from L. fermenti 126 which are equal to $2.0,1.1,0.9$, and 1.7 , respectively. In case of L. rhamnosus CCM 1825 biosurfactant showed absorbance coefficients for bands $\mathrm{AmI} / \mathrm{CH}$, AMII/CH, $\mathrm{PI} / \mathrm{CH}$, and PII/CH with higher values of equal to $2.5,1.4,1.2$, and 2.1, respectively. Researchers [48] also compared absorbance coefficients and concluded that minor differences are present in the chemical structure of both types of biosurfactants.

Fascinating report on biosurfactant production from L. fermentum RC-14, L. rhamnosus GR-1 and 36, L. casei Shirota which contained proteins with a capacity to bind to both collagen types. These studies by Howard et al. [44] were supported through surface-enhanced laser desorption ionization - time of flight mass spectrometry.
Among all three types, biosurfactants from RC-14 predominately indicated the presence of higher number collagen-binding proteins. With these techniques, authors tried to report the use of surface-enhanced laser desorption ionization like system for rapid characterization of complex biosurfactants solutions.

In the oral cavity, S. mutans is one of the known grampositive bacterium predominantly responsible for formation of dental biofilm. The polymers namely glucans and fructans, an extra cellular polysaccharides facilitates the adherence of these cocci-shaped bacteria on tooth surface. Due to unusual capacity of $S$. mutans to adhere on tooth and initiate development of biofilms ultimately leading to dental caries. The gene cassette $g t f B, g t f C$, and gtfD encoding the synthesis of polymer secretions and therefore, is an impending target for defence against oral cavity caries [61]. Single attempt is recorded on this aspect by Tahmourespour et al. [49] showing the production of protein-like cell associated biosurfactant from L. acidophilus DSM 20079 which interferes in the adhesion and also $S$. mutans biofilm formation. The cell associated biosurfactant could make streptococcal chains shorter. Authors tried to verify the data through real time reverse transcription polymerase chain reaction (RT-PCR) quantitation and showed the evidence of decrease in expression of $g t f B$ and $g t f C$ genes in the presence of cell associated biosurfactant. Tahmourespour et al. [49] attempted to analyze that cell associated biosurfactant through Fourier transform infrared spectroscopy technique pointing out the dominance of protein components with major bands at $2933 \mathrm{~cm}^{-1}$ (CH band: CH2-CH3 stretching), $1653 \mathrm{~cm}^{-1}$ (AmI band: CAO stretching in proteins), $1480 \mathrm{~cm}^{-1}$ (AmII band: NOH bending in proteins) with $1248 \mathrm{~cm}^{-1}$ (PI band: phosphates) and $1099 \mathrm{~cm}^{-1}$ (PII band: polysaccharides). As a result authors anticipated the presence of protein as one of the major components in addition to a polysaccharide and phosphate in the biosurfactant produced by L. acidophilus. Thus on the basis of their findings, cell associated biosurfactant can effectively hamper with adhesion processes of $S$. mutans on teeth surfaces. These studies are momentous to depict the role of cell associated biosurfactant as antimicrobial, antiadhesive, and antibiofilm agent and affecting the expression level of extracellular enzymes of glucosyl transferases (GTFs) in S. mutans biofilms.

Glycolipid. The production of glycolipid complex containing carbohydrate (mono or oligo saccharide) and lipid moiety with surface active properties is widely accepted in case of Pseudomonas spp. Whereas, in case of Lactobacillus spp. the majority of the literature appears to be protein-based biosurfactant. There are few exceptions 


\title{
Journal of Basic Microbiology
}

\author{
Surekha K. Satpute et al.
}

where glycolipid-type biosurfactant obtained from Lactobacilli spp. Sharma and Singh Saharan [30] used L. casei MRTL3 as biosurfactant producing strain and reported glycolipid-type biosurfactant analyzing through thin-layer chromatographic studies. The presence of lipid and sugar moieties in biosurfactant was confirmed using ${ }^{1} \mathrm{H}$-Nuclear magnetic resonance spectroscopy. The presence of methyl esters glycolipid biosurfactant was correlated to an increased hydrophobicity and, as a result enhancing not only the biosurfactant surface activity but also hemolytic and antifungal activities. Sharma et al. [24] reported again glycolipid-type biosurfactant from Lactobacilli spp. having mixture of sugar and lipid fractions which was claimed to be similar to xylolipid. Fourier transform infrared spectroscopy and nuclear magnetic resonance analysis confirmed the presence of glycolipid with hexadecanoic fatty acid (C16) chain. Fourier transform infrared spectroscopy technique has been proved as one of the most significant technique routinely followed to investigate the functional groups of unknown compound [30].

Glycoprotein. As mentioned previously in the above paragraphs, proteinaceous biosurfactants have been generally reported by Lactobacilli spp. In Fourier transform infrared spectroscopy analysis, glycoproteintype biosurfactant are observed in the typical absorbance maxima at wavelengths ranges between 3500 and $1500 \mathrm{~cm}^{-1}$ with a characteristic of stretching $\rightarrow \mathrm{N}-\mathrm{H}$ bonds and $\mathrm{CO}-\mathrm{N}$ and $\mathrm{N}=\mathrm{O}$ bonds, confirming the incidence of proteins in the sample under analysis. The absorption peak around 3000 corresponds to the presence of bonds occurring in aliphatic chains $(-\mathrm{CH} 3,-\mathrm{CH} 2-)$. The indication of a spectrum over wavelength range of $1200-1000 \mathrm{~cm}^{-1}$ signifies the polysaccharide fraction of BS while very strong absorption at wavelength of $1087.2 \mathrm{~cm}^{-1}$ indicates $\mathrm{C}-\mathrm{O}-\mathrm{C}$ bonds. Recent contribution by Madhu and Prapulla [23] observed protein and polysaccharide fractions typical of glycoprotein in BS isolated from L. plantarum CFR 2194. The Fourier transform infrared spectroscopy revealed a nonhomogeneous structure consisting of protein and polysaccharide fractions. Madhu and Prapulla [23] also suggested that the composition of biosurfactant complex is definitely affected by the various components present in the media used in the fermentation process as well as phase of growth of the biosurfactant synthesizing organism. Glycoprotein-based biosurfactant extracted from L. agilis CCUG31450 reduces surface tension of water to $42.5 \mathrm{mN} \mathrm{m}^{-1}$, had a critical micelle concentration $(\mathrm{cmc})$ of $7.5 \mathrm{mg} \mathrm{ml}^{-1}$ with high emulsifying activity $\left(E_{24}=60 \%\right)[31]$.
Gołek et al. [32] reported on a L. casei 8/4 producing glycoprotein type BS rich in proteinaceous nature with polysaccharide as one of the major fractions. A characteristic Fourier transform infrared spectroscopy excitation spectra at wavelengths of (1546 and $\left.1653 \mathrm{~cm}^{-1}\right), \quad\left(1547\right.$ and $\left.1653 \mathrm{~cm}^{-1}\right)$, and $(1549$ and $1655 \mathrm{~cm}^{-1}$ ) confirms protein fractions and excitation spectra for polysaccharides fraction were detected at wavelengths of 1066,1068 , and $1073 \mathrm{~cm}^{-1}$. The evidence for phosphoric groups was observed by excitations spectra that occurred at wavelengths 1236,1238 , and $1240 \mathrm{~cm}^{-1}$, respectively. Authors put forward the similar opinion in agreement with Madhu and Prapulla [23] explaining the importance of media composition and growth condition with respect to determination of structural characteristics of proteins in glycoproteins. Gołek et al. [32] also reported biosurfactant (without structure elucidation) from L. fermenti 126, L. acidophilius PG 8/4, L. casei rhamnosus CCM 1825 and showed their anti-adhesion activities against Klebsiella pneumonia on intestinal epithelial cells (using Caco-2 cell line).

Glycolipopeptide. The cell associated biosurfactant complexes of having chemical composition of glycolipopetide are rarely cited. Since huge structural complexity is associated with glycolipopetide-type biosurfactants, very few species of Lactobacilli are known for their production. Vecino et al. [33] reported the production cell associated from L. pentosus with a fatty acid (in hydrophobic chain portion) based composition including linoelaidic acid, oleic, elaidic acid, palmitic acid, and stearic acid. The authors proposed that fatty acid chains in cell associated biosurfactant are very much similar to the fatty acid containing fractions detected in rhamnolipid biosurfactant (originated from Pseudomonas strains). Moldes et al. [25] characterized glycoprotein or a glycolipopeptide-type biosurfactant produced from L. pentosus using Fourier transform infrared spectroscopy analysis showing occurrence of $\mathrm{OH}$ and $\mathrm{NH}$ groups, $\mathrm{C}=\mathrm{O}$ stretching of carbonyl groups and $\mathrm{NH}$ bending (peptide linkage) and also $\mathrm{CH}_{2}-\mathrm{CH}_{3}$ and $\mathrm{C}-\mathrm{O}$ stretching indicating the presence of lipid fractions. Such characteristic spectra of biosurfactant have been reported from several lactic acid bacteria.

Cell associated biosurfactant with no structure details. Literature survey illustrates that the majority of work on cell associated biosurfactant explored is mainly for their antimicrobial, anti-adhesive, and antibiofilm characteristics. However, huge basin remains untouched without revealing the detailed structural and chemical composition related to cell associated biosurfactant. Basically the structural complexity may the most probable hindrance to reveal the unexposed information. Since 1996 up to 


\section{Journal of Basic Microbiology}

1999, the very limited literature had discussed the production of BS. In the year of 1999, Reid et al. [42] added valuable work in this regards. Authors used L. fermentum RC14 strain for biosurfactant production in de Man, Rogosa, and Sharpe medium and showed that those complex molecules can inhibit adhesion of commonly found uropathogens in female urinary tract. Velraeds et al. [43] worked with several strains of Lactobacilli including L. fermentum B54, L. rhamnosus 36, and L. rhamnosus ATCC $7469^{\mathrm{T}}$ and reported proteinaceous kind biosurfactant without much elucidation of structural components. Rodrigues et al. [13] extensively worked toward media optimization for biosurfactant production from various Lactobacilli spp.

Walencka et al. [34] also reported a biosurfactant produced by L. acidophilus (no description of structural characteristics) which inhibits biofilms development in $S$. aureus and S. epidermidis affecting initial adhesion, biofilm formation, and cells dispersal. It was suggested that the addition of biosurfactant to preformed mature biofilms leads to rapid dispersion and alters the morphological changes of biofilm structures due to altering cell-surface hydrophobicity of the tested bacteria. This can ultimately hamper the deposition rate as well as development of biofilm.

Sambanthamoorthy et al. [51] investigated BS production by L. jensenii and L. rhamnosus and carried out in vitro studies on antimicrobial, anti-adhesive, and antibiofilm abilities of the cell-bound BS (structure not described) against various pathogens such as multidrug resistant E. coli, S. aureus, and Acinetobacter baumannii. On similar aspects Gomaa [35] reported cell free biosurfactant and cell associated biosurfactant production (without any detailed description) using L. acidophilus, L. brevis, L ruteri. Researchers namely, Gan et al. [14], Gudiña et al. [15-17], Kermanshahi et al. [62], Moldes et al. [54] reported several Lactobacilli spp. for production of cell free biosurfactant and cell associated biosurfactant with antimicrobial and anti-adhesive properties. However, it is important to note that no structural details are available on those biosurfactants.

Very few studies have been contributed toward understanding the role of Lactobacillus-derived BS on gene expression conferring the virulence properties to biofilm forming bacteria. For example, Tahmourespour et al. [49] initiated studies (discussed previously) and later demonstrated by Salehi et al. [52] indicating the effects of cell associated biosurfactant purified from L. reuteri (DSM20016) on the gene expression profile of essential adhesion genes (gftB/C and $\mathrm{ftf}$,) in $S$. mutans (ATCC35668). The cell associated biosurfactant (structure not described) has been proved as potential inhibitor of the glucosyltransferases and fructosyltransferase in S. mutans (ATCC35668). It is very important to note that the inhibition is predominantly advantageous due to its selectivity in action and does not hamper other microbiota inside the mouth other than $S$. mutans. L. rhamnosus-derived crude cell associated biosurfactant inhibit biofilms produced by potential pathogenic bacteria viz., S. aureus and P. aeruginosa. Cell associated biosurfactant work effectively to affect the growth and antibacterial and anti-adhesive in association with polyvinyl alcohol-biosurfactant mixture in glass and plastic plates [52].

\section{Biomedical-related role of Lactobacilli-derived biosurfactant}

One of the main physiological roles of the Lactobacilli spp. in the gastrointestinal tract is the prevention of the proliferation of harmful pathogenic bacteria. However, this may not be true when they are associated with dental caries [63]. Several Lactobacillus spp. are part of the human and animal commensal intestinal flora. They are considered to be protective organisms which prevent the growth of pathogenic organisms through the production of lactic acid and other metabolites creating an acidic environment which inhibits the growth of some harmful bacteria. Various anti-infective properties of Lactobacilli spp. are illustrated in Fig. 2.

Isolating members of Lactobacilli can be difficult. Regular media namely nutrient broth or Luria broths are commonly used for the growth and maintenance of bacterial cultures may not usually support the growth of this genus. Growing Lactobacilli need special nutrient provision (like de Man, Rogosa, and Sharpe medium) and sometimes extended incubation periods and members are likely to get wrongly identified due to their morphological resemblance to other bacterial genera such as Corynebacterium, Streptococcus, and Clostridium [64]. Even though, species of Lactobacilli is generally considered to be protective organism in healthy humans, some critical issues regarding potential pathogenicity have been explained in the immune-compromised patients [4]. Some researchers have suggested that possible infections can be caused by Lactobacillus spp. in the acquired immune deficiency syndrome patients having neutropenia or following organ transplantation [65]. Endocarditis, bacteremia, neonatal meningitis, dental caries, abscesses, and chorioamnionitis are all types of clinical infections reported so far by Lactobacilli [63]. Post-adhesion competitions against uropathogens are the main significant features that are contributed by Lactobacilli. Major inhibitory effects on 


\section{Journal of Basic Microbiology}

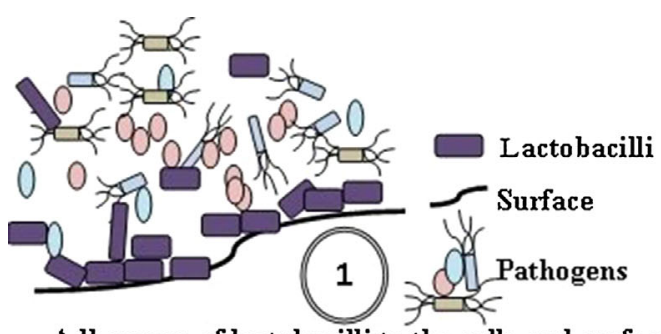

Adherence of lactobacilli to the cells and surfaces (epithelial cells, or medical devices) and hamper the adhesion of pathogens (Competitive exclusion)

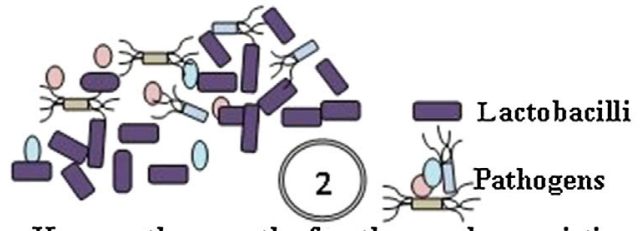

Hamper the growth of pathogens by persisting and multiplying; produce acids, $\mathrm{H}_{2} \mathrm{O}_{2}$, and

bacteriocins antagonistic to pathogen growth

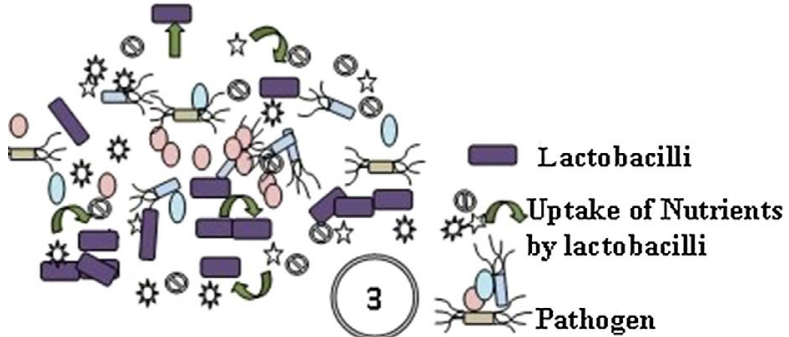

Uptake of nutrients by Lactobacilli and deplete them to pathogens

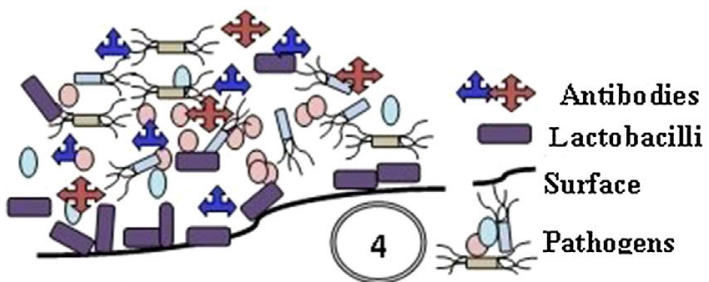

Amend the host immune response and surrounding environment to reduce the risk of infection

Figure 2. Illustration of four different ways for anti-infective properties of Lactobacilli spp.

the initial deposition and adhesion of some uropathogens have been demonstrated by Velraeds et al. [2, 5, 6]. However, some Lactobacilli spp. may not show initial inhibition of uropathogenic E. faecalis [65].

Cytotoxicity ultimately leads to loss of cell membrane integrity resulting in cell lysis or necrosis. Most biologically produced secondary metabolites such as antibiotics, polypeptides, proteins, etc. may have cytotoxic effects to some extent and have to be tested to establish suitability for health-related applications. Lack of cytotoxic effects is therefore important for consideration of application related to human health, from a safety point of view [24]. Literature suggests that in addition to antimicrobial, anti-adhesive, and antibiofilm properties, biosurfactant obtained from Lactobacillus spp. do possess cytotoxic effect. This is supported by Sharma et al. [24] who investigated the cytotoxic effect of L. helveticus-derived biosurfactant using a mouse fibroblast (ATCC L929) cell line. They reported that as the concentration of biosurfactant increased $(6.25-25 \mathrm{mg}$ $\mathrm{ml}^{-1}$ ) there was a gradual decreased in cell viability. Cell viability of $30.9 \%$ was determined at the concentration of $25 \mathrm{mg} \mathrm{ml}^{-1}$ and was similar to commonly used rhamnolipid (as positive control) which showed $32.87 \%$ of cell viability at similar concentration.

Sambathammorthy et al. [51] also determined cytotoxicity of biosurfactant derived from two strains L. jensenii and L. rhamnosus using human lung epithelial cell line (A549). The cytotoxicity of the crude biosurfactant was evaluated in two ways, firstly by the release of lactate dehydrogenase and secondly by total cell number assay. No toxicity was observed at the concentrations of 25-100 $\mathrm{mg} \mathrm{ml}^{-1}$ and low toxicity levels were observed at $200 \mathrm{mg} \mathrm{ml}^{-1}$ by both biosurfactant extracts. In conclusion, the limited literature available to this subject appears to confirm that biosurfactants originated from Lactobacillus spp. has low cytotoxic effect comparable to commercially available rhamnolipids which are generally considered nontoxic products. This makes them potential safe candidates for use in biomedical application particularly as topical delivery products.

\section{Role of low-cost fermentative media in biosurfactant production}

The use of various cheaper renewable substrates such as distillery wastes, animal fat, molasses, plant oils, oil wastes, and starchy substances, lactose containing whey and oil industries are common in the fermentation industries. Three major aspects are needed to be considered to increase the biosurfactant production at commercial scale. The first is improvement in the fermentation technology followed by use of cheaper, renewable substrates and their continued reliable supply. Table 2 presents a brief listing of the variety 


\section{Journal of Basic Microbiology}

Biosurfactant/s from Lactobacilli species

Table 2. Summary for various raw substrates used for production of different types of biosurfactant from Lactobacilli spp.

\begin{tabular}{|c|c|c|c|c|}
\hline $\begin{array}{l}\text { Name of } \\
\text { the } \\
\text { organisms }\end{array}$ & $\begin{array}{l}\text { Cheaper substrates used in the production } \\
\text { process }\end{array}$ & $\begin{array}{l}\text { Type/composition of } \\
\text { biosurfactant (BS) }\end{array}$ & $\begin{array}{l}\text { Yield of } \\
\text { biosurfactant }\end{array}$ & References \\
\hline $\begin{array}{l}\text { L. pentosus } \\
\text { CECT-4023 }\end{array}$ & Cheese whey and molasses & Crude BS & $\begin{array}{l}\text { Pmax }=1.4 \mathrm{~g} \mathrm{~L}^{-1} \\
\text { and } r \mathrm{p} / \\
X=0.093 \mathrm{~g} \mathrm{~L}^{-1} \\
\text { per } \mathrm{h}\end{array}$ & [13] \\
\hline $\begin{array}{l}\text { L. agilis } \\
\text { CCUG31450 }\end{array}$ & Cheese whey & Glycoprotein & $960 \mathrm{mg} \mathrm{L}^{-1}$ & {$[31]$} \\
\hline L. pentosus & $\begin{array}{l}\text { Grape marc after supplementation with corn } \\
\text { steep liquor }\left(10 \mathrm{~g} \mathrm{~L}^{-1}\right) \text { and yeast extract }\left(10 \mathrm{~g} \mathrm{~L}^{-1}\right)\end{array}$ & Intracellular BS & $4.8 \mathrm{mg} \mathrm{L}^{-1}$ & {$[66]$} \\
\hline L. pentosus & Grape marc & $\begin{array}{l}\text { BS } \\
\text { Composition not mentioned }\end{array}$ & $5.9 \mathrm{~g} \mathrm{~L}^{-1}$ & {$[67]$} \\
\hline L. pentosus & $\begin{array}{l}\text { - Hemicellulosic sugar hydrolyzates obtained } \\
\text { from trimming vine shoots } \\
\text { - Barley bran husk hydrolyzates }\end{array}$ & $\begin{array}{l}\text { BS } \\
\text { Composition not mentioned }\end{array}$ & $\begin{array}{l}-0.71 \mathrm{~g} \text { of BS per } \\
\mathrm{g} \text { of biomass } \\
-0.28 \mathrm{~g} \text { of BS per } \\
\mathrm{g} \text { of biomass }\end{array}$ & {$[54]$} \\
\hline L. pentosus & $\begin{array}{l}\text { - Sugars from agricultural distilled grape marc } \\
\text { hydrolyzates } \\
\text { - Low-cost feedstock agricultural residues as } \\
\text { substrates: hazelnut shells, distilled grape marc, } \\
\text { walnut shells }\end{array}$ & $\begin{array}{l}\text { BS } \\
\text { Protein fractions probably } \\
\text { associated with bound } \\
\text { phosphate }\end{array}$ & Not mentioned & [68] \\
\hline L. delbrueckii & Peanut oil cake & $\begin{array}{l}\text { Glycolipid with carbohydrate } \\
\text { and lipid combination of } \\
30 \%: 70 \%(\mathrm{w} / \mathrm{w})\end{array}$ & $5.35 \mathrm{mg} \mathrm{ml}^{-1}$ & [8] \\
\hline L. pentosus & Vineyard pruning waste & Glycolipopeptide & Not mentioned & {$[25]$} \\
\hline L. pentosus & Vineyard pruning waste & BS rich in protein content & $\begin{array}{l}\text { Ranging between } \\
0.29 \text { and } \\
1.35 \mathrm{mg} \mathrm{L}^{-1}\end{array}$ & {$[50]$} \\
\hline
\end{tabular}

Note: Pmax, maximum concentration of biosurfactant $\left(\mathrm{gL}^{-1}\right) ; r \mathrm{p}$, initial volumetric rate of biosurfactant formation $\left(\mathrm{gL}^{-1} \mathrm{~h}^{-1}\right)$.

of suitable cheap raw substrates used in biosurfactants production. Low yield of biosurfactant at industrial level is the main problem faced by industries in addition to the high cost inputs essential to run large scale fermentations. Usage of renewable substrates could provide an alternative solution toward advancement of the process. A variety of renewable substrates that can be used for large scale production including agro-industrial waste, animal fat waste, coffee processing residues, dairy industry, distillery industry industrial effluents, food processing industry, fruit processing industry, oil processing mills were all reported [69]. Cheese whey has been exploited as an alternative medium at commercial level [70] where L. pentosus CECT-4023 reported to be a very strong biosurfactant producing strain [13]. Enhanced yield of glycoprotein (from 84 up to $960 \mathrm{mg} \mathrm{L}^{-1}$ ) has been achieved from Lactobacilli spp. [31].

Agricultural residues are one of the abundant and easily accessible carbon sources for biosurfactant production, most, however, need some pre-treatments. A lignocellulosic material often needs acid hydrolysis and thermal treatment followed by a clarifying step. Portilla-Rivera et al. [66-68] and Paradelo et al. [71] used such media for BS production from L. pentosus and obtained products comparable to surfactin produced by Bacillus subtilis in terms of hydrocarbon emulsification abilities and potential uses in bioremediation. Paradelo et al. [71] concluded that L. pentosus grown on grape marc hydrolysates for BS production, it can reduce the water repellence of hydrophobic material, which is very much better in comparison to chemical-based surfactants. Large-scale production of biosurfactants has become possible by the usage of hemicellulosic sugars from vineyard pruning waste.

Other examples, where hemicellulosic sugars from vineyard pruning waste were utilized for biosurfactant production using Lactobacillus have been reported as steps toward reducing environmental impact of waste disposal [25]. Comparative studies on the kinetics of sediment sorption on biosurfactant obtained from L. pentosus and two chemical surfactants viz., Tween 20 and sodium dodecyl sulfate have been carried out. Their studies showed that no sodium dodecyl sulfate is 


\section{Journal of Basic Microbiology}

adsorbed onto the sediments, whereas Tween 20 and biosurfactants from L. pentosus are absorbed after a few minutes. In addition to agricultural waste substrates, diary-based products have a crucial role in biosurfactant industries. Since, most of the Lactobacillus strains used for biosurfactant production are either isolated from dairy based products or of human origin. Various oils have been proved as best substrates for biosurfactants production from genus Lactobacillus. Thavasi et al. [8] tried to grow L. delbrueckii in peanut oil cake supplemented media and yielded $5.35 \mathrm{mg} \mathrm{ml}^{-1}$ of biosurfactant. Their studies have a great impact on demonstrating that biosurfactants alone have the capacity to enhance the biodegradation of crude oil up to greater extent in absence of fertilizers. Even though biosurfactant production from Lactobacilli spp. work has been documented in the literature since long time, inadequate scientific reports are available on biosurfactant production from Lactobacilli spp. using cheap and renewable substrates. It is important to highlight that few reports do discuss on biosurfactant production using Lactobacillus spp. by using agriculture residues [71]. In spite of the availability of huge number of renewable substrates, hardly any work has been investigated on this aspect. Biosurfactant derived from lactic acid bacteria has tremendous scope in industrial sectors and therefore, need to explore on broader scale [72].

\section{Future prospects}

Lactobacilli produced biosurfactants appear to have great biomedical potential applications. In the field of biosurfactants and related production technology, we are actively in search of novel strains capable of utilizing cheaper, renewable substrates, greater yields, and novel applications. Several numbers of industries are vigorously seeking suitable surface active molecules with advanced applications. Huge possible opportunities are available today in this field for designing new biosurfactant-based formulations which may have high market demand. The composition of most of the biosurfactants has not been fully elucidated. The diverse competence of biosurfactants produced by probiotic bacteria toward therapeutic approaches can be highly significant. It has been suggested that utilizing these surface active molecules in preventing and/or dealing with hospitalacquired infections may be an important undertaking. Other promising applications include inhibiting microbial biofilm formation and the prevention of urogenital infection in mammals in addition to use as an adjuvants to conventional antibiotics in the treatment of hospital- acquired diseases or infections. This needs much more attention so that those surface active molecules can be utilized for several applications in diverse fields.

\section{Acknowledgments}

Dr. Surekha K. Satpute is highly grateful to Department of Science and Technology (DST), Government of India, Ministry of Science and Technology, New Delhi, India for financial support (SR/WOS-A/LS-1076/2014(G)). Without DST's financial support, it would not have been possible to conduct this work. Constant support from the Director, School of Basic medical Sciences, Department of Physics, Savitribai Phule Pune University is also acknowledged.

\section{Conflict of interest}

The authors report no conflicts of interest.

\section{References}

[1] Coeuret, V., Dubernet, S., Bernardeau, M., Gueguen, M., et al., 2003. Isolation, characterization and identification of Lactobacilli focusing mainly on cheeses and other dairy products. Lait, 83, 269-306.

[2] Velraeds, M.M.C., van der Mei, H.C., Reid, G., Busscher, H.J., 1997. Inhibition of initial adhesion of uropathogenic Enterococcus faecalis to solid substrata by an adsorbed biosurfactant layer from Lactobacillus acidophilus. Urology, 49, 790-794.

[3] Kyla-Nikkila, K., Hujanen, M., Leisola, M., Palva, A., 2000. Metabolic engineering of Lactobacillus helveticus CNRZ32 for production of pure L-(+)-lactic acid. Appl. Environ. Microbiol., 66, 3835-3841.

[4] Harty, D.W., Oakey, H.J., Patricks, M., Hume, E.B., et al., 1994. Pathogenic potential of Lactobacilli. Int. J. Food Microbiol., 24, 179-189.

[5] Velraeds, M.M.C., van der Mei, H.C., Reid, G., Busscher, H., 1996. Inhibition of initial adhesion of uropathogenic Enterococcus faecalis by biosurfactants from Lactobacillus isolates. Appl. Environ. Microbiol., 62, 1958-1963.

[6] Velraeds, M.M.C., van der Mei, H.C., Reid, G., Busscher, H.J., 1996. Physicochemical and biochemical characterization of biosurfactants released by Lactobacillus strains. Coll. Surf. B, 8, 51-61.

[7] Velraeds, M.M.C., van de Belt-Gritter, B., van der Mei, H.C., Reid, G., et al., 1998. Interference in initial adhesion of uropathogenic bacteria and yeasts to silicone rubber by a Lactobacillus acidophilus biosurfactant. J. Med. Microbiol., 47, 1081-1085.

[8] Thavasi, R., Jayalakshmi, S., Banat, I.M., 2011. Application of biosurfactant produced from peanut oil cake by Lactobacillus delbrueckii in biodegradation of crude oil. Bioresour. Technol., 102, 3372-3666. 


\section{Journal of Basic Microbiology}

Biosurfactant/s from Lactobacilli species

[9] Blomberg, L., Hendriksson, A., Conway, P.L., 1993. Inhibition of adhesion of Escherichia coli K88 to piglet Ileal mucus by Lactobacillus spp. Appl. Environ. Microbiol., 59, 4-39.

[10] Satpute, S.K., Banpurkar, A.G., Banat, I.M., Sangshetti, J.N., et al., 2016. Multiple roles of biosurfactants in biofilms. Curr. Pharm. Des., 22, 429-448.

[11] Ceresa, C., Tessarolo, F., Caola, I., Nollo, G., et al., 2015. Inhibition of Candida albicans adhesion on medical-grade silicone by a Lactobacillus-derived biosurfactant. J. Appl. Microbiol., 118, 1116-1125.

[12] Rodrigues, L., Banat, I.M., Teixeira, J., Oliveira, R., 2006. Biosurfactants: potential applications in medicine. J. Antimicrob. Chemother., 57, 609-618.

[13] Rodrigues, L., Moldes, A., Teixeira, J., Oliveira, R., 2006. Kinetic study of fermentative biosurfactant production by Lactobacillus strains. Biochem. Eng. J., 28, 109-116.

[14] Gan, B.S., Kim, J., Reid, G., Cadieux, P., et al., 2002. Lactobacillus fermentum RC-14 inhibits Staphylococcus aureus infection of surgical implants in rats. J. Infect. Dis., 185, 1369-1372.

[15] Gudiña, E.J., Rocha, V., Teixeira, J.A., Rodrigues, L.R., 2010. Antimicrobial and antiadhesive properties of a biosurfactant isolated from Lactobacillus paracasei ssp. paracasei A20. Lett. Appl. Microbiol., 50, 419-424.

[16] Gudiña, E.J., Teixeira, J.A., Rodrigues, L.R., 2010. Isolation and functional characterization of a biosurfactant produced by Lactobacillus paracasei. Coll. Surf. B, 76, 298-304.

[17] Gudiña, E.J., Teixeira, J.A., Rodrigues, L.R., 2011. Biosurfactant-producing lactobacilli: screening, production profiles, and effect of medium composition. Appl. Environ. Soil Sci., 2011, 1-9.

[18] Reid, G., Bruce, A., Smeianov, V., 1998. The role of Lactobacilli in preventing urogenital and intestinal infections. Int. Dairy. J., 8, 555-562.

[19] Schachtsiek, M., Hammes, W.P., Hertel, C., 2004. Characterization of Lactobacillus coryniformis DSM 20001 T surface protein Cpf mediating coaggregation with and aggregation among pathogens. Appl. Environ. Microbiol., 70, 7078-7085.

[20] Voltan, S., Castagliuolo, I., Elli, M., Longo, S., et al., 2007. Aggregating phenotype in Lactobacillus crispatus determines intestinal colonization and TLR2 and TLR4 modulationinmurine colonic mucosa. Clin. Vaccine Immunol., 14, 1138-1148.

[21] Satpute, S.K., Banpurkar, A.G., Dhakephalkar, P.K., Banat, I.M., et al., 2010. Methods for investigating biosurfactants and bioemulsifiers: a review. Crit. Rev. Biotech., 30, 127-144.

[22] Fracchia, L., Banat, J.J., Cavallo, M., Ceresa, C., et al., 2015. Potential therapeutic applications of microbial surfaceactive compounds. AIMS Bioeng., 2, 144-162.

[23] Madhu, A.N., Prapulla, S.G., 2014. Evaluation and functional characterization of a biosurfactant produced by Lactobacillus plantarum CFR 2194. Appl. Biochem. Biotechnol., 172, 1777-1789.

[24] Sharma, D., Singh Saharan, B., Chauhan, N., Bansal, A., et al., 2014. Production and structural characterization of Lactobacillus helveticus derived biosurfactant. The Scientific World J., 2014, 1-9.
[25] Moldes, A.B., Paradelo, R., Vecino, X., Cruz, J.M., et al., 2013. Partial characterization of biosurfactant from Lactobacillus pentosus and comparison with sodium dodecyl sulphate for the bioremediation of hydrocarbon contaminated soil. BioMed. Res. Int., 2013, 1-9.

[26] Fracchia, L., Cavallo, M., Allegrone, G., Martinotti, M.G., 2010. A Lactobacillus-derived biosurfactant inhibits biofilm formation of human pathogenic Candida albicans biofilm producers, in: Méndez-Vilas, A. (Ed.), Current Research, Technology and Education Topics in Applied Microbiology and Microbial Biotechnology (Microbiology Book Series, No. 2, vol. 2), FORMATEX, Spain. pp. 827-837. ISBN-13: 978-84-614-6195-0.

[27] Augustin, M., Hippolyte, M.T., 2012. Screening of biosurfactants properties of cell-free supernatants of cultures of Lactobacillus spp. isolated from a local fermented milk (Pendidam) of Ngaoundere (Cameroon). Int. J. Eng. Res. Appl., 2, 974-985.

[28] Augustin, M., Hippolyte, M.T., Raïssa, K.R., 2013. Antibacterial activity of Lactobacillus' biosurfactants against Pseudomonas spp. isolated from fresh beef. Novus Int. J. Biotechnol. Biosci., 2, 7-22.

[29] Salman, J.A.S., Alimer, A.D., 2014. Lactobacillus rhamnosus against some bacteria causing utiiniraqi women. Int. J. Curr. Res., 6, 5368-5374.

[30] Sharma, D., Singh Saharan, B., 2014. Simultaneous production of biosurfactants and bacteriocins by probiotic Lactobacillus casei MRTL3. Inter. J. Microbiol., 2014, 1-7.

[31] Gudiña, E.J., Fernandes, E.C., Teixeira, J.A., Rodrigues, L.R., 2015. Antimicrobial and anti-adhesive activities of cell-bound biosurfactant from Lactobacillus agilis CCUG31450. RSC Adv., 5, 909-960.

[32] Gołek, P., Bednarski, W., Brzozowski, B., Dziuba, B., 2009. The obtaining and properties of biosurfactants synthesized by bacteria of the genus Lactobacillus. Ann. Microbiol., 59, 119-126.

[33] Vecino, X., Barbosa-Pereira, L., Devesa-Rey, R., José, M.C., et al., 2015. Optimization of extraction conditions and fatty acid characterization of Lactobacillus pentosus cell-bound biosurfactant/bioemulsifier. J. Sci. Food Agric., 95, 313-320.

[34] Walencka, E., Różalska, S., Sadowska, B., Różalska, B., 2008. The influence of Lactobacillus acidophilus - derived surfactants on staphylococcal adhesion and biofilm formation. Folia Microbiol., 53, 61-66.

[35] Gomaa, E.Z., 2013. Antimicrobial and anti-adhesive properties of biosurfactant produced by Lactobacilli isolates, biofilm formation and aggregation ability. J. Gen. Appl. Microbiol., 59, 425-436.

[36] Díaz De Rienzo, M.A., Stevenson, P., Marchant, R., Banat, I.M., 2016. Antibacterial properties of biosurfactants against selected Gram-positive and -negative bacteria. FEMS Microbiol. Lett., 363(2):fnv224, 1-8.

[37] Fracchia, L., Cavallo, M., Martinotti, M.G., Banat, I.M., 2012. Chapter 14, Biosurfactants and bioemulsifiers biomedical and related applications - present status and future potentials. in: Ghista, D. N. (Ed.), Biomedical Science, Engineering and Technology, InTech, Rijeka, Croatia, Europe, pp. 325-370. ISBN: 978-953-307-471-9, DOI $10.5772 / 23821$ 


\section{Journal of Basic Microbiology}

[38] Marchant, R., Banat, I.M., 2012. Biosurfactants: a sustainable replacement for chemical surfactants? Biotechnol. Lett., 34, 1597-1605.

[39] Marchant, R., Banat, I.M., 2012. Microbial biosurfactants: challenges and opportunities for future exploitation. Trends Biotechnol., 11, 558-565.

[40] Satpute, S.K., Banat, I.M., Dhakephalkar, P.K., Banpurkar, A.G., et al., 2010. Biosurfactants, bioemulsifiers and exopolysaccharides from marine microorganisms. Biotechnol. Adv., 28, 436-450.

[41] Banat, I.M., Franzetti, A., Gandolfi, I., Bestetti, G., et al., 2010. Microbial biosurfactants production, applications and future potential. Appl. Microbiol. Biotechnol., 87, 427-444.

[42] Reid, G., Heinemann, C., Velraeds, M., van der Mei, H.C., et al., 1999. Biosurfactants produced by Lactobacillus. Methods Enzymol., 310, 426-433.

[43] Velraeds, M.M.C., van de Belt-Gritter, B., Busscher, H.J., Reid, G., et al., 2000. Inhibition of uropathogenic biofilm growth on silicone rubber in human urine by Lactobacilli - a teleologic approach. World. J. Urol., 18, 422-426.

[44] Howard, J.C., Heinemann, C., Thatcher, B.J., Martin, B., et al., 2000. Identification of collagen-binding proteins in Lactobacillus spp. with surface-enhanced laser desorption/ ionization-time of flight protein chip technology. Appl. Environ. Microbiol., 66, 4396-4400.

[45] Gołek, P., Bednarski, W., Lewandowska, M., 2007. Characteristics of adhesive properties of Lactobacillus strains synthesising biosurfactants. Polish J. Natural Sci., 22, 333-342.

[46] Shokouhfard, M., Kermanshahi, R.K., Shahandashti, R.V., Feizabadi, M.M., et al., 2015. The inhibitory effect of a Lactobacillus acidophilus derived biosurfactant on biofilm producer Serratia marcescens. Iran J. Basic Med. Sci., 18, 1001-1007.

[47] Fouad, H.K., Khanaqa, H.H., Munira, Ch.I., 2010. Purification and characterization of surlactin produced by Lactobacillus acidophilus. IRAQI Acad. Sci. J., 8, 34-39.

[48] Brzozowski, B., Bednarski, W., Gołek, P., 2011. The adhesive capability of two Lactobacillus strains and physicochemical properties of their synthesized biosurfactants. Food Technol. Biotechnol., 49, 177-186.

[49] Tahmourespour, A., Salehi, R., Kermanshahi, R.K., Eslami, G., 2011. The anti-biofouling effect of Lactobacillus fermentum-derived biosurfactant against Streptococcus mutans. Biofouling, 27, 385-392.

[50] Vecino, X., Devesa-Rey, R., Cruz, J.M., Moldes, A.B., 2013. Evaluation of biosurfactant obtained from Lactobacillus pentosus as foaming agent in froth flotation. J. Environ. Manag., 128, 655-660.

[51] Sambanthamoorthy, K., Feng, X., Patel, R., Patel, S., et al., 2014. Antimicrobial and antibiofilm potential of biosurfactants isolated from Lactobacilli against multi-drugresistant pathogens. BMC Microbiol., 14, 197.

[52] Salehi, R., Savabi, O., Kazemi, M., Kamali, S., et al., 2014. Effects of Lactobacillus reuteri-derived biosurfactant on the gene expression profile of essential adhesion genes (gtfB, gtfC and ftf) of Streptococcus mutans. Adv. Biomed. Res., 3, 169.
[53] Reid, G., Cuperus, P.L., Bruce, A.W., van der Mei, H.C., et al., 1992. Comparison of contact angles and adhesion to hexadecane of urogenital, dairy, and poultry lactobacilli: effect of serial culture passages. Appl. Environ. Microbiol., $58,1549-1553$.

[54] Moldes, A.B., Torrado, A.M., Barral, M.T., Domianguez, J.M., 2007. Evaluation of biosurfactant production from various agricultural residues by Lactobacillus pentosus. J. Agric. Food Chem., 55, 4481-4486.

[55] Campos, J.M., Stamford, T.L., Sarubbo, L.A., de Luna, J.M., et al., 2013. Microbial biosurfactants as additives for food industries. Biotechnol. Prog., 29, 1097-1108.

[56] Rodrigues, L.R., van der Mei, H.C., Teixeira, J.A., Oliveira, R., 2004. Influence of biosurfactants from probiotic bacteria on formation of biofilms on voice prosthesis. Appl. Environ. Microbiol., 70, 4408-4410.

[57] De Man, J.C., Rogosa, M., Sharpe, M.E., 1960. A medium for cultivation of Lactobacilli. J. Appl. Bacteriol., 23, 130-135.

[58] Bergström, S., Theorell, H., Davide, H., 1946. On a metabolic product of Ps. pyocyania. pyolipic acid active against M. tuberculosis. Arkiv. Kemi. Mineral. Geol., 23A, $1-12$.

[59] Arima, K., Kakinuma, A., Tamura, G., 1968. Surfactin, a crystalline peptide lipid surfactant produced by Bacillus subtilis: isolation, characterization and its inhibition of fibrin clot formation. Biochem. Biophys. Res. Commun., 31, $488 Đ 494$.

[60] Munira, Ch.I., Kadhim, M.I., Mayasaa, Kh.Al-M., 2013. The effect of surlactin produced by Lactobacillus acidophilus on eye infectious bacteria in rabbits. J. Baghdad Sci., 10, 133-142.

[61] Chia, J.S.H., Teng, T.Y., Chen, L.J., Hahn, J.Y., et al., 1991. Glucosyltransferase gene polymorphism among Streptococcus mutans strains. Infect. Immun., 59, 1656-1660.

[62] Kermanshahi, R.K., Peymanfar, S.H., 2012. Isolation and identification of Lactobacilli from cheese, yoghurt and silage by $16 \mathrm{~S}$ rDNA gene and study of bacteriocin and biosurfactant production. Judishapur J. Microbiol., 5, 528-532.

[63] Holliman, R.E., Bone, G.P., 1988. Vancomycin resistance of clinical isolates of Lactobacilli. J. Infect., 16, 279-283.

[64] Schlegel, L., Lemerle, S., Geslin, P., 1998. Lactobacillus species as opportunistic pathogens in immunocompromised patients. Eur. J. Clin. Microbiol. Infect. Dis., 17, 887-888.

[65] Reid, G., Bruce, A.W., Busscher, H.J., van der Mei, H.C., 2000. Lactobacillus therapies. United State Patent. US006051552A, Patent no. 6,051,552.

[66] Portilla-Rivera, O.M., Moldes, A.B., Torrado, A.M., Dominguez, J.M., 2007. Lactic acid and biosurfactants production from hydrolyzed distilled grape marc. Proc. Biochem., 42, 1010-1020.

[67] Portilla-Rivera, O.M., Moldes, M.A.B., Torrado Agrasar, A.M., Domínguez González, J.M., 2007. Biosurfactants from grape marc: stability study. J. Biotechnol., 131S, S136.

[68] Portilla-Rivera, O., Torrado, A., Dominguez, J.M., Moldes, A.B., 2008. Stability and emulsifying capacity of biosurfactants obtained from lignocellulosic sources using Lactobacillus pentosus. J. Agric. Food Chem., 56, 8074-8080. 


\title{
Journal of Basic Microbiology
}

\author{
Biosurfactant/s from Lactobacilli species
}

19

[69] Banat, I.M., Satpute, S.K., Cameotra, S.S., Patil, R., et al., 2014. Cost effective technologies and renewable substrates for biosurfactants' production. Front. Microbiol., 5, 697.

[70] Rodrigues, L.R., Teixeira, J.A., 2008. Biosurfactants production from cheese whey, in: Cerdán, M.E., GonzálezSiso, M.I., Becerra, M. (Eds.), Advances in Cheese Whey Utilization, Transworld Research Network, Kerala, India, 2008. pp 81-104. ISBN 978-81-7895-359-5.

[71] Paradelo, R., Moldes, A.B., Dominguez, J.M., Barra, M.T., 2009. Reduction of water repellence of hydrophobic plant substrates using biosurfactant produced from hydrolyzed grape marc. J. Agric. Food Chem., 10, 4895-4899.

[72] Sharma, D., Singh Saharan, B., Shailly, K., (Ed.), 2016. Biosurfactants of lactic acid bacteria. eBook ISBN. 978-3319-26215-4. Springer Briefs in Microbiology. Springer International Publishing AG Switzerland. DOI 10.1007/ 978-3-319-26215-4 